Res Philosophica 95 (2018): 421-447. (please cite published version)

\title{
God and Interpersonal Knowledge
}

\author{
Matthew A. Benton
}

$\mathrm{E}$

PISTEMOLOGY has focused largely on propositional knowledge, that is, on how we can know facts about the world. But another kind of knowledge has been largely overlooked by philosophers, a kind of knowledge we seem to have earliest in our cognitive development, and which we care very deeply about: knowledge of persons, especially what we have when we know someone "personally." On recent accounts, ${ }^{1}$ interpersonal knowledge differs substantially from knowledge of propositions about persons. If propositional knowledge may be glossed as a state of mind, ${ }^{2}$ consisting in a subject's attitude to a (true) proposition, this account thinks of interpersonal knowledge as a state of minds, involving a subject's attitude to another (existing) mind. Roughly, interpersonal knowledge is had when two individuals know each other personally, as subjects, from the second-person perspective.

An epistemology which recognizes and incorporates interpersonal knowledge holds promise for illuminating several issues in philosophy of religion, and for advancing a distinctive approach to religious epistemology. Some have gestured at similar ideas, but without offering a developed epistemology of persons, and without sorting out the epistemological connections between perceptual contact, propositional or qualitative knowledge about persons, knowing-how to interact with someone, and knowing someone personally or in relationship. ${ }^{3}$ The present essay seeks to fill this need, while demonstrating how broad and deep the applications can be.

Section 1 develops and refines an account of interpersonal knowledge,

${ }^{1}$ Lauer (2014), Code (2015, section 4), Talbert (2015), and Benton (2017), on which we will focus. Cf. also Stump (2010, 2013), to be discussed in section 2.

${ }^{2}$ See especially Williamson $(2000 ; 2009,293-301)$, as well as Nagel (2013).

3E.g. Moser (2008, 55-6o on 'volitional' knowing; 2010, 210ff. on 'filial' knowing; and 2014,153 on 'redemptive friendship'), as well as Greco (2008, 56ff. and 2017, 10-11, 21), and Wolterstorff (2016). 
and clarifies its relation to the propositional knowledge one might have about other persons. Section 2 considers our knowledge of God and God's knowledge of us, and compares interpersonal knowledge with work by Eleonore Stump on "Franciscan" knowledge. Section 3 examines how interpersonal knowledge may figure in liturgical practice, diffusing the problem of divine hiddenness, and motivating a novel understanding of divine love. Finally, section 4 explores the possibility of epistemic injustice arising from dismissal or neglect of our religious testimony to one another, or of divine testimony to humanity, focusing specifically on the import of interpersonal knowledge.

\section{$1 \quad$ Interpersonal Knowing}

Knowing someone "personally" is arguably very different from having propositional knowledge about them, or from having qualitative knowledge of (say) what they look like, their mannerisms, mood patterns, and so on. The latter in its various forms might best be called objectual knowledge, ${ }^{4}$ on the model of perceiving (and retaining in memory) an object; the structure of such knowledge, however, also seems apt to knowing a city, or a a field of study. ("He knows Boston." "She knows English literature.") Yet when one knows someone personally the "object" of cognition is a subject, a person. Not only do our languages distinguish such knowledge relations either lexically or grammatically, ${ }^{5}$ but intuitively, knowing someone personally is not reducible to knowing a lot (propositions or qualitatively) about them.

Distinguishing between this knowledge about someone and interpersonal knowledge may be facilitated by noting three grades of personal involvement. The first grade is achieved by having propositional knowledge of facts about a person, gained without first-hand causal interaction with the person. Such knowledge is typically gained second-hand from others: thus one can know

${ }^{4}$ For work on objectual knowledge, see McGrath 2017 and Schieber 2017.

${ }^{5}$ E.g. in Spanish, there are saber and conocer; in German, kennen and wissen; in French, connaître and savoir. Comparable lexical distinctions are made in Polish, modern Hebrew, and Mandarin and Cantonese. In languages like English, where a single lexical item "know" can express either relation, nevertheless there are grammatical formulations which make explicit which meaning is intended. And there are syntactic rules (revealed by conjunction reduction tests, or substitution behavior) governing how each may be used. See Benton $(2017,814-819)$ for more. 
"by description" all manner of facts about someone through, say, reading newspapers or hearing about them from friends. By contrast, the second grade of personal involvement enables one to get a bit more intimately involved with someone: one is thus involved when one gains propositional (or qualitative) knowledge about a person through perceptual access to the person, though it need not be perception of the person "in the flesh" (images of someone might suffice to learn what they look like). Such knowledge, whether qualitative or propositional, is learned first-hand, and the causal direction is one-way, from the person to the knower. Knowledge from both of these grades of involvement is plausibly knowledge-who, that is, knowledge by which one might be able to identify or individuate a person, in answer to a question about them.

But notice that neither of these first two grades of involvement suffice for knowing someone personally (the relation I am also labelling "interpersonal knowledge"). A spy or a biographer might have excellent knowledge-who deriving from first or second grade personal involvement without knowing their subjects personally. Likewise, two people might have excellent knowledge of each other by working in the same institution and learning about each other from web research, or internal literature, or from the say-so of colleagues. They recognize each other's faces, they might go to the same committee meetings and hear each other offer suggestions, and so on. But if they've never addressed each other in conversation or properly met, it would seem they don't yet know each other personally. Plausibly, no amount of knowledge-who (propositional or qualitative) can bring it about that one knows another subject personally.

Interpersonal knowledge thus is not the kind of thing that can be built up out of knowing more and more propositions about someone, or by gaining more qualitative knowledge of them. And interpersonal knowledge is autonomous relative to any particular propositions known about a person, in this sense: for any set of propositions one knows about someone, one could in principle know that someone personally without knowing those particular propositions about them.

Thus there is something special about the third grade of personal involvement, which requires a kind of second-personal treatment. When both per- 
sons treat each other in this way, and each receives such treatment, the involvement is distinctively interpersonal: it requires a kind of contact with another subject where each treats the other as a subject, that is, how an "I" treats another as a particular "you". ${ }^{6}$ And differently from the first two grades of knowing, when interpersonal the causal route is two-way, running both directions between subjects. Arguably these two-way interactions make up the (low-level) mindreading and resonance processes undergirding recent discoveries in cognitive science concerning simulation, mirror neurons, and joint attention, and thus these are fundamental to knowing another person secondpersonally. ${ }^{7}$ The required second-person stance involves each person treating the other as a subject, for example in the language of address, or in joint attention to objects or topics of conversation. ${ }^{8}$ Treating someone secondpersonally involves "I-you," subject-to-subject interaction, wherein some of what one learns about others is learned from, because it is given to one by, the persons themselves.

The following principle seems to capture what kinds of encounters are required for a person to know another subject personally (that is, have interpersonal knowledge of them, abbreviated as "knows $i$ "):

ENCOUNTER: $\mathrm{S}$ knows $_{i} \mathrm{R}$ only if (i) $\mathrm{S}$ has had reciprocal causal contact with $\mathrm{R}$, in which (ii) $\mathrm{S}$ treats $\mathrm{R}$ second-personally, and (iii) $\mathrm{R}$ treats $\mathrm{S}$ second-personally.

A treatment by a subject $S$ toward its recipient $R$ is second-personal in virtue of $\mathrm{S}$ treating $\mathrm{R}$ as a subject (an individual "you”), where $\mathrm{S}$ offers some of S's own thoughts, words, or emotions to $R$, and $S$ is, or for the most part intends to be, attentive to R's thoughts, words, or emotions. Such contact between them is reciprocal insofar as each shares with the other some of their

\footnotetext{
${ }^{6}$ The third grade of personal involvement is entered when one subject treats the other second-personally. But because, atypically, this treatment might be one-way by not being received, or not being reciprocated, the paradigmatic kind of third-grade involvement is interpersonal, with each treating the other as a subject.

7See Goldman (2006, Chaps. 6-7, and 2013, esp. Chaps. 2-5), and Stump (2010, esp. Chap. 4).

${ }^{8}$ See Eilan $(2014,2016)$ for an overview of recent work on second-personal approaches.
} 
own thoughts, words, or emotions in response to the other. We might say that such reciprocal encounters bring the mind of the known subject itself right into the subjective life of the knower's mind, and thus their occasion for interpersonal knowing is, as our gloss has it, a state of minds meeting.

We can motivate the importance of both directions of such second-personal treatment by imagining a world where all its minds are capable of thinking first-personal "I" thoughts, and third-personal "he/she/it" thoughts, but lack the ability (and language) for "you" thoughts: in such a world, intuitively, no one would count as knowing personally anyone else. Likewise, we might imagine a world where just one person has the needed second-personal ability but no one else does; plausibly that individual also fails to know others personally, because they lack the two-way reciprocal personal encounters needed to gain interpersonal knowledge.

Through personal encounters, people can progress from being mere acquaintances to being friends, to close friends, to intimates or lovers. Increase in personal encounters, once there are enough of them, makes for interpersonal knowing. Given the importance of such two-way interactions, we might be led to think that interpersonal knowledge is also symmetric:

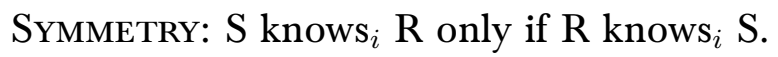

Given this principle, interpersonal knowledge between two subjects is lost for both if it is lost for one. Symmetry is not redundant given Encounter, for one could fulfill the latter by having had the right kind of contact in the past, even though the person encountered no longer lives. Thus SymmetRY captures a condition that mimics the factivity of propositional knowledge, according to which one can only know truths or facts: to know another interpersonally, there must be a mind there to be known.

Some may regard SyMmETRY and perhaps even ENCOUNTER as too strong. Such theorists may want to allow that, while the paradigms of interpersonal knowing are indeed two-way and fulfill ENCOUNTER, nevertheless the one-way second-personal treatment by $\mathrm{S}$ toward $\mathrm{R}$ by which $\mathrm{S}$ enters the third grade of involvement is necessary and sometimes sufficient for $\mathrm{S}$ to know $\mathrm{R}$ personally, even though $\mathrm{R}$ may not know S personally (if so, then such one-way cases fail 
not only Symmetry, but also clauses (i) and (iii) of Encounter). While I find this implausible, I shall remain largely neutral on this matter here; I shall later, however, sketch some potential costs and benefits of denying at least Symmetry. For now I shall simply note that deniers of Symmetry should endorse a principle (a consequence of SYMMETRY) on which a person can know another subject personally only if the person known exists. ${ }^{9}$ For intuitively, persons who no longer exist, or never did exist, are not interpersonally known. Understanding interpersonal knowledge as a state of minds requires the existence of both minds.

This existence requirement fits in well with skeptical concerns and deductive closure; for one might suspect that knowing another mind puts one in a very strong position concerning knowing that they exist. When thinking along these lines, it will seem that skepticism about other minds can be quite easily dispensed with. Consider the principle that propositional knowledge is closed under known entailment, (SPC):

Single Premise Necessarily, if $\mathrm{S}$ knows that $p$, competently deduces $q$, and Closure: thereby comes to believe that $q$, while retaining knowledge that $p$ throughout, then $\mathrm{S}$ knows that $q{ }^{10}$

Knowledge that one has interpersonal knowledge will then be thought to obey the following closure principle, a simple application of SPC (where ' $p$ ' is replaced by the proposition that $\mathrm{S}$ knows $_{i} \mathrm{R}$ ):

Closure: Necessarily, if $\mathrm{S}$ knows that $\mathrm{S}$ knows $_{i} \mathrm{R}$, competently deduces $q$, and thereby comes to believe that $q$, while retaining knowledge that $\mathrm{S}$ knows $_{i} \mathrm{R}$ throughout, then $\mathrm{S}$ knows that $q$.

Replacing ' $q$ ' with the proposition that $\mathrm{R}$ exists, which is entailed by the

${ }^{9}$ To know human subjects, the requirement would be that they have earthly existence, such that their existence permits causal (spatio-temporal) access to them. This principle may be modified to allow for cases of the afterlife; but in the afterlife, such subjects may not plausibly count as human.

${ }^{10}$ See Hawthorne $(2004,34)$; cf. also Dunaway and Hawthorne (2017) for more on Closure principles applied to issues concerning knowledge and God. 
existence requirement (or the SYMmETRY condition), we get an existential application of SPC:

Exists: Necessarily, if $\mathrm{S}$ knows that $\mathrm{S} \operatorname{knows}_{i} \mathrm{R}$, competently deduces that $\mathrm{R}$ exists, and thereby comes to believe that $\mathrm{R}$ exists, while retaining knowledge that $\mathrm{S}$ knows $_{i} \mathrm{R}$ throughout, then $\mathrm{S}$ knows that $\mathrm{R}$ exists.

Thus by CLOSURE one could come to know that those whom one personally knows exist. But the skeptical threat about other minds is not so easily dismissed, because such inference by way of CLOSURE only helps if one knows that one has such interpersonal knowledge; and such propositional knowledge may sometimes be hard to come by, depending on the subject in question and one's context of knowing. For example, Mary Jane knows personally Peter Parker, and thereby also knows personally Spiderman; but (at an early stage of the Spiderman story) she does not believe, and plausibly disbelieves, that she knows Spiderman personally. She might even (at that early stage) believe, falsely, that Spiderman does not exist, though of course, she knows that Peter Parker exists. Thus the state of minds that constitutes interpersonal knowing is not luminous (in Williamson's sense: 2000, Ch. 4).

What could it be to talk of interpersonal knowledge as a state of minds or a 'mental state'? Philosophers of mind and epistemologists regard as paradigms the propositional attitude mental states of belief or desire, whose logical form involves a monadic predicate: a mind is in a state having a certain kind of content. Perhaps that content can be propositional/representational or qualitative (such as feeling pain), but however the content is filled in, the logical form is that of an individual mind (named by the individual constant $a$ ) being in a state construed as bearing a property (expressed by the predicate letter $F$ ), thus: $F a$. But there are plausibly mental states that can be understood in terms of a three-place relation, as do some polyadic predicates, the form of which includes an additional constant, e.g. the dyadic relation: Fab. ${ }^{11}$ While some mental states may be irreducibly monadic in structure, others may take either monadic or polyadic form: Allie $(a)$ might be (just plain) angry $(A a)$, though not at any particular fact or person; but she might instead be angry

\footnotetext{
${ }^{11}$ Broad (2014 [1925], 570) recognized this possibility.
} 
at Blake $(A a b)$. This latter relation is a mental state of Allie having the person Blake as object. Finally, some mental states may be irreducibly polyadic (for example, being jealous of, or being suspicious of). Since we plausibly have independent reason to recognize that mental states can be polyadic in structure and include more than one individual, we may proceed as if there are such mental states and that interpersonal knowledge is one such relation.

The basic contours of interpersonal knowledge are now laid out. Most recent work in religious epistemology has attended to skepticism about theism, focusing on the rationality of believing that there is a God. Though important, we shall examine related epistemological matters which go well beyond whether one believes or knows that there is a God; our interest is what impact interpersonal knowledge can have on a host of issues in philosophy of religion. For the sake of argument, then, we shall suppose that there is a personal God something like that of the monotheistic traditions-roughly, a divine creator that is exceedingly powerful, knowledgeable, and morally good-and that it is in principle possible for one to know, interpersonally, that being as Divine subject. We shall consider precedents for this view, and then see how it might matter to divine hiddenness, liturgy, divine love, and epistemic injustice.

\section{Interpersonal knowledge between God and us}

Several philosophers and theologians have maintained that relating to God second-personally, as Divine subject, and having something like interpersonal knowledge of God, is a central aspect of religious faith. For example, Anselm engages these ideas in his most famous text: as Marilyn McCord Adams (1995) shows, in the Proslogion Anselm's genre is that of the alloquium, "in which the soul speaks to God" in the form of "second-person address to God, at intervals combining this with exclamations of thanks and praise" (1995, 18-19). Likewise Søren Kierkegaard's pseudonym Johannes Climacus writes:

Let us take the knowledge of God as an example. Objectively, what is reflected upon is that this is the true God; subjectively, that the individual relates himself to a something in such a way that his relation is in truth a God-relation. ... The existing person 
who chooses the objective way now enters upon all approximating deliberation intended to bring forth God objectively, which is not achieved in all eternity, because God is a subject and hence only for subjectivity in inwardness. (Postscript, $199^{2}$ [1846], 199-200)

It is noteworthy that Kierkegaard also emphasizes related themes in the signed authorship. ${ }^{12}$

Similarly, a young John Rawls (2009 [1942]) writes:

...the "religious" appetition... found in the works of Plato, Aristotle, Augustine, and Aquinas... is the coping-stone of the natural cosmos. In short, it is the appetition which seeks God as its object, or the Form of the Good, the Alone and so forth. It is the appetition directed to the highest object, to the source of all Beauty, Truth, and Goodness. ... To have such an appetition is to sin. To the writer it is sheer impiety to desire God as an object. ... To speak of God as the most beautiful object, the most satisfying object, the most desired of all objects is to sin, because one of the forms of sin, as we shall see, is to turn a personal relation into a natural relation, and to do this misdeed in relation to God is surely sin. (182)

Natural theology is helpless before the personality of God. Why? Because all knowledge of other persons is knowledge given to us by them. Personal knowledge is revealed knowledge. It comes about through communication in community. Natural objects immediately disclose their nature; but persons must consent to communicate knowledge of themselves. ${ }^{13}$ (224)

\footnotetext{
${ }^{12}$ E.g. the Upbuilding Discourses: "This view, that to need God is a human being's highest perfection, does indeed make life more difficult, but it also views life according to its perfection, and in this view a person, through the piecemeal experience of [this need], which is the right understanding with God, comes to know God" (Kierkegaard 1990 [1843-44], 321ff.). For more on Kierkegaard's use of the subjective, interpersonal stance toward God, see Cockayne 2017.

${ }^{13}$ Such language is echoed by Talbert, who insists that "the other must consent to be known” (2015, 203).
} 
Both Kierkegaard and Rawls tie the epistemic relation of knowing God to the propriety of relating to God as a subject in personal relations, rather than as a propositional fact. More recently, Bas van Fraassen (2002, 192-93) emphasizes similar points, while acknowledging that "for much contemporary philosophy this domain of interpersonal knowledge and interaction is simply terra incognita” (p. 192):

an encounter with the divine is a personal encounter. ... An encounter with God does not involve solving a theoretical equation or answering a factual query; its searing question is an existential demand we face in fear and trembling. As with a human person, the encounter coincides with a call to decision: possible stances toward ourselves and to our world come to the fore and ask for choice (van Fraassen 2002, 193).

Related themes concerning God's giving Godself to us to be known as subject are found in Gregory of Nazianzus, ${ }^{14}$ Martin Buber (1970 [1923]), Karl Barth, ${ }^{15}$ and Emil Brunner (1943, esp. Chap. 2), among many others. ${ }^{16}$

More recently, Eleonore Stump (2009, 2010) argues that analytic philosophy of religion has fallen prey to a particularly objectifying form of inquiry

${ }_{14}$ "And [God] does this, it seems to me, so that to the extent that the Divine can be comprehended it may draw us to itself-for what is completely incomprehensible is also beyond hope, beyond attainment; and that to the extent that it is beyond our comprehension it might stir up our wonder, and through wonder might be yearned for all the more, and through our yearning might purify us, and in purifying us might make us like God; and when we have become this, that he might then associate with us intimately as friends-my words here are rash and daring! — uniting himself with us and making himself known to us as God to gods, perhaps to the same extent that he already knows those who are known by him." Orations 38.7, cited in Beeley (2008, 102-103).

15 "If God gives Himself to man to be known in the revelation of His Word through the Holy Spirit, it means that $\mathrm{He}$ enters into the relationship of object to man the subject. ... In His triune life as such, objectivity, and with it knowledge, is divine reality before creaturely objectivity and knowledge exist. We call this the primary objectivity of God, and distinguish it from the secondary, i.e., the objectivity which He has for us too in His revelation, in which He gives Himself to be known by us as He knows Himself." Barth, Church Dogmatics II.1, (2000 [1957]), 9 and 16). Cf. Church Dogmatics I.1, (1975 [2nd edn.], 135).

${ }^{16}$ See also William James $(1912,23,27)$; Basil Mitchell (in Flew and MacIntyre 1955, 103105, and Mitchell 1973, 140); C.S. Lewis (1955; cf. Wielenberg 2008, 158-164 for discussion); and Austin Farrer (in Mitchell 1958, 21-23 and 91ff.). 
about God, and she admirably deploys her own view of second-personal knowledge in handling the problem of evil. On Stump's approach, what she calls "Franciscan knowledge of persons" is similar in some ways to the notion of interpersonal knowing developed here. She initially characterizes Franciscan knowledge negatively, simply in terms of "irreducibility to knowledge that," acknowledging that she cannot give a set of necessary and sufficient conditions $(2010,47-48,51)$. Instead, Stump suggests that we can grasp what Franciscan knowledge is by drawing on Frank Jackson's $(1982,1986)$ case of Mary, wherein Mary's new experience gains her a qualitative, what-it-is-like knowledge (Stump 2010, 52). Taking the original Mary case as inspiration, Stump asks us to consider a different Mary, who is imprisoned her whole life in a room wherein she learns all manner of facts about the world and others only through third-personal factual accounts, and without "any personal interactions of an unmediated and direct sort with another person," the kind "in which one can say 'you' to another person." Mary would, upon emerging from this room to meet her loving mother for the first time, begin to gain much qualitative, what-it-is-like knowledge of being touched and loved by another person, but also a kind of personal, Franciscan knowledge: she would begin to know her mother $\left(2010,5^{2}\right)$. This Franciscan knowledge of persons then is distinguished from other kinds of knowledge about persons, including propositional knowledge (which Stump likens to "Dominican" knowledge: 2010, 47-51).

Stump sometimes talks as if "the direct and immediate encounter with another human," in "face-to-face... interpersonal interactions" is crucial for gaining Franciscan knowledge of someone $\left(2010,5^{2-53}\right)$; but she also claims, on the same page, that "any direct causal contact between the knower and the person known" is "not necessary" to gain it $\left(2010,5^{2}\right)$. This is because Stump thinks that Franciscan knowledge of persons can be acquired primarily by way of narratives, the hearing of which constitutes a kind of second-personal engagement with the person(s) of the narrative.

However, because of these emphases, Stump is committed to the idea that one can "know" (personally, in her Franciscan sense) people who do not exist, for example, fictional characters and dead people (2010, 53, 78-79). Thus Stump must deny the highly plausible closure principle ExISTs, which 
we discussed in section 1. Yet these consequences seem quite counterintuitive: for how could one know someone personally, or Franciscanly, who does not exist? Is there no room for a bare ontology of persons to undergird the conditions for knowing such persons? What is more, comparing a case of $\mathrm{S}$ knowing personally someone who exists, with that of S knowing (in Stump's Franciscan sense) a fictional character, reveals that the former relation is both more natural and a relation of genuine epistemic interest: knowing an existing person brings a kind of cognitive connection with the social world of actual persons. ${ }^{17}$

Stump's difficulty here extends to her idea that God may be known personally, or Franciscanly, by way of second-personal treatment. For it would seem that one could have Franciscan knowledge of God even if there is in fact there is no God. For Stump, the only thing which makes the difference would seem to be the knower's treating some character or object as a person, as an "I" to an individual "you," even if what is so treated is not a person or there is no such thing to receive said treatment. For Stump, one of the primary ways one could engage in such treatment would be by reading or hearing the Biblical narratives in the way they demand: as narratives of a personal God's story to us and with us, through which we understand God in second-personal terms. ${ }^{18}$ But if there is in fact no God and such stories arise purely out of human myths, shouldn't we instead say that we do not know personally, or even Franciscanly, God? For in that case there would be no being there to be known. ${ }^{19}$

This raises the question of how Stump's primary application of Franciscan

${ }^{17}$ Recently Stump seems to acknowledge that there might be a problem here, at least with entirely fictional characters $(2017,187 \mathrm{nn}$. 23 and 24; cf. 2010, 521 n. 98); but she does not consider it further.

${ }^{18}$ There is evidence from cognitive science that reading narratives of speculative fiction offers a much richer engagement (e.g. through transportation and empathy) than reading third-personal accounts (De Smedt and De Cruz 2015). But my concern is epistemic, namely the question of what (or whom) one is actually brought into cognitive contact with through reading second-personal narratives.

${ }^{19}$ One can get the feeling that Stump may be presupposing something like a descriptivist theory of names, according to which the characters of a narrative must refer to someone with the properties delineated in the narrative, and it is that person (even if fictional) to whom one relates second-personally and thereby knows Franciscanly. Yet such descriptivist theories have been well criticized, if not refuted, in work by Kripke (1972) and others. 
knowledge, to the problem of evil, is supposed to succeed. For how does it help with the problem of evil to urge that we might know God personally, in the Franciscan sense, if one could acquire such knowledge without there being a God? One might worry that it does little to respond to the problem of evil if the knowledge supposedly relating us to God neither entails, nor even makes probable, that there is a God; this is all the more magnified for the person struggling with how the kinds and amounts of evil we find in the world make it unlikely that there is a God. ${ }^{20}$ By comparison, if our account of interpersonal knowledge sketched earlier is correct, it will result in a very different situation concerning evidence, interpersonal knowing, and the issue of skepticism about the existence of God: on our approach, knowing God interpersonally can ${ }^{21}$ ground one's faith in the face of evil, even suffering experienced and lived through while in relation to God.

\section{Hiddenness, Liturgy, and Divine Love}

While, as we've just seen, several philosophers suggest that knowing God through second-personal treatment of God is an important aspect of the religiously devoted theist, there are several things that can be said, and have yet to be said, about our epistemic position concerning God's existence and how we might be thought to cognize or interact with God. Here I shall sketch some new arguments and directions which interpersonal knowledge makes possible for the problem of divine hiddenness, the epistemology of liturgy, and an account of divine love.

\subsection{Divine Hiddenness}

Might it be possible to know God personally without even believing that God exists? J.L. Schellenberg (1993, 2015a, 2015b) has answered a nearby question

\footnotetext{
${ }^{20}$ Though some have lodged nearby concerns with Stump's Franciscan knowledge (e.g. Rea 2009, 91, Fischer 2012, Feldbacher 2012; see Stump 2012 for some replies), I have found no one raising the specific epistemological worries I am voicing here.

${ }^{21}$ Perhaps if other epistemic relations remain intact: such as believing that there is a God whom one knows personally, in part because one regards one's second-personal experiences with God to have been sufficiently reciprocated. But the details here can remain messy, as the discussion of divine hiddenness below reveals.
} 
in the negative, and used this denial as support for a premise in a hiddenness argument for skepticism about traditional theism.

In its most succinct form, Schellenberg's argument runs:

(1) If a loving God exists, then there are no nonculpable nonbelievers.

(2) There are nonculpable nonbelievers.

So, (3) No loving God exists.

When spelled out more fully, his support for premise (1) concerns a defense of sub-premises, typically along the lines of one of the following:

(4) If there is a perfectly loving God, all creatures capable of explicit and positively meaningful relationship with God who have not freely shut themselves off from God believe that God exists. (Schellenberg 2008, §2)

(5) If for any capable finite person $S$ and time t, God is open to being in a personal relationship with $\mathrm{S}$ at $\mathrm{t}$, then for any capable finite person $S$ and time $t$, it is not the case that $S$ is at $t$ nonresistantly in a state of nonbelief in relation to the proposition that God exists. (2015a, 25)

Schellenberg's recent defense of such premises appeals to the following general principle about persons, their beliefs, and being open to relationship:

Not Open Necessarily, if a person A, without having brought about this condition through resistance of personal relationship with a person $\mathrm{B}$, is at some time in a state of nonbelief in relation to the proposition that B exists, where $B$ at that time knows this and could ensure that A's nonbelief is at that time changed to belief, then it is not the case that $B$ is open at the time in question to having a personal relationship with A then. (2015a, 23; cf. 2015b, 57) 
Let us suppose, as seems highly plausible, that knowing another personally, along the lines of interpersonal knowledge discussed earlier, counts as a personal relationship of the kind Schellenberg has in mind in Not Open. ${ }^{22}$

Recall, however, from our discussion in section 2 that human persons can know others personally while disbelieving, under a certain guise, that they exist. For Mary Jane can believe that Spiderman does not exist even though she knows Peter Parker personally (and believes that Parker exists). ${ }^{23}$ Given this much, it should be clear that Not Open, which is supposed to be a fully general principle applying to all persons and what it is for them to be open to personal relationship, is false. And since Schellenberg relies on Not Open to derive premises like (5), his hiddenness argument clearly fails.

The above counterexample likewise calls into question passages where Schellenberg assumes that it is "impossible" to "do or experience any of the" myriad things "involved in a conscious, reciprocal relationship [with God] if she does not believe that God exists" (2015a, 25). To repair his argument, Schellenberg would need to supplement it in order for his principle Not Open to be plausible: he would need to offer a guise theory which spells out under what guise or description one must believe that the person with whom one is in relationship exists. ${ }^{24}$ Yet this kind of repair seems to be a tall order, for we noted in sectionı that interpersonal knowing is autonomous relative to any particular propositions known (or even believed) about the person. Indeed, as has been argued elsewhere, one can know personally someone about whom one has all, or nearly all, false beliefs: e.g. a conman, who by interacting (via our third grade) with the subject he wants to exploit, will misrepresent himself in every way, thereby causing her to have entirely

\footnotetext{
${ }^{22}$ Indeed, it is perhaps even a stronger relation than what Schellenberg needs; but if so, the point made next will show that his principle does not hold even when assuming this stronger relation.

${ }^{23}$ Cullison (2010) offers related counterexamples where a person A can continue on in meaningful relationship with someone $\mathrm{B}$, where A formerly believed B exists, but A now suspends judgment concerning B's existence (because A is not confident that $\mathrm{B}$ is still alive); cf. also related points by Greco (2015); Cuneo (2016, 57); and Stump (2017, 182), discovered after the present paper was completed. My example, however, is different because Mary Jane does not even start off believing, under the right guise, that Spiderman exists.

${ }^{24}$ And articulating a general guise theory is complicated enough; see Goodman and Lederman unpub.
} 
false beliefs about his (intrinsic) properties. No doubt we will judge that she doesn't know the conman very well at all, since knowing someone well typically requires knowing some truths about someone, and of the kind that would rationally ground putting one's trust in them. But for all that, there is still someone whom she knows personally: namely, the conman (Benton 2017, 827).

\subsection{Liturgical knowledge}

Some have suggested that liturgically mediated experience of God can offer resources for handling concerns about divine hiddenness or at least divine silence (Rea 2009). Recent discussions of knowing God through liturgical practices also emphasize the importance of relating to God in a second-personal way. ${ }^{25}$ However, such discussions normally do not clarify whether through liturgical engagement one acquires mere perceptual contact with God, or objectual (or qualitative) knowledge of God, or practical knowledge-how to relate to God, or what we are calling interpersonal knowledge with God.

For example, some claim that liturgical acts "can be ways of experiencing the mediated presence of God" in something akin to the way that narrative commemorative events "mediate the presence of the events which they commemorate" (Rea 2009, 92). But what epistemic relation might such mediated experience bring about? Is it like gaining qualitative knowledge of what someone looks like by seeing only a picture of them, or more like gaining a general understanding (or propositional knowledge) of someone you never met solely by hearing stories of them at their funeral? By comparison, Sarah Coakley sketches many different ways in which liturgical practices could have epistemic import (cf. 2013, 134), yet is content to embrace its many relations and capacities in their intertwined complexity. ${ }^{26}$ Terence Cuneo, for his part, argues that "knowing God" in the sense of "being in rapport with" God "is a

\footnotetext{
${ }^{25}$ See especially Coakley 2013; Cuneo 2016, esp. Ch. 8; and Wolterstorff 2016 and 2018.

26 “...what is distinctive to liturgical 'knowing,' I have argued, is the way that bodily movement, sensual acuity, affective longing, and noetic or intellectual response, are intricately entwined and mutually implicated in what is occurring, and indeed are being trained over time to intensify and deepen their capacity for response to the risen Christ." (Coakley 2013, 143-144).
} 
species of practical knowledge" of the sort had by "knowing how to engage with God," and that such practical knowledge comes through ritualized liturgical activities: indeed, "knowing God... consists in engaging in them (Cuneo $2016,149,162)$. Still others claim an order of dependence in which practical knowledge precedes perceptual ability: that ecclesial practices enable "knowhow," which itself facilitates the development of a kind of perception, that is, "a tacit perceptual knowing acquired through such mentored practices as prayer, contemplation, fasting, and mercy... a knowing how to attend to God's presence in the world." That is, "human beings, when transformed through ecclesial practices, become progressively more capable of perceiving God" (McGuigan and Kallenberg 2017, 152). But is this mere perceptual contact? Or qualitative knowledge? Given the many possibilites invoked by just these above examples, it seems clear that philosophers of liturgy need to sort out the relations between these cognitive states and abilities, and to elaborate more fully how they are or are not gained through ritual engagement with the divine.

This is not the place to attempt to provide such a satisfactory account of these many possible relations which philosophers of liturgy might have in mind. Yet if we suppose that interpersonal knowledge is the ideal relation through which God unites God's self to humans, then one proposal is to view interpersonal knowledge-being in a joint state of minds with the divine mind - as the resultant cognitive relation which can only be gained by ascending through perceptual contact to objectual knowledge, by way of our third-grade of personal involvement, which treats God second-personally as a subject, through prayer, worship, and liturgical participation; and that this stage of participation importantly involves gaining propositional knowledge, and perhaps even understanding, of the correct guises or descriptions which apply to God. ${ }^{27}$ If we suppose that learning how to do all of this this involves learning the practical skill of relating to God through such practices, ${ }^{28}$ and that cultivating such practices is part of how one learns to recognize God's responsive actions to us, we can think of liturgy as facilitating both percep-

\footnotetext{
${ }^{27}$ If so, this of course raises issues concerning religious diversity, particularly which descriptions of God are the correct ones, or those by which one can plausibly fix the reference of one's language for God. Unfortunately we don't have space to consider these here.

${ }^{28}$ See also Sliwa (2018, esp. 259-26o).
} 
tual recognition and personal knowledge-how, and ultimately, interpersonal knowledge. Yet however one might attempt to sort out the details, I submit that an understanding of what knowing God through liturgy amounts to can profit by adopting the distinctions made by an epistemological account of interpersonal knowledge such as that outlined above.

\subsection{Divine love}

Finally, interpersonal knowledge has a role to play in motivating a novel account of divine love. Recent prominent approaches to human love diverge over whether one must have a past history of relationship with those whom one loves. I shall argue here that if one appropriates and extends any such view to divine love for human creatures, the possibility and desirability of interpersonal knowledge between God and us contributes crucial insights that are otherwise unavailable.

Two early approaches differ on whether the characteristics valued by the lover in the beloved are prioritized over whom is beloved, or whether the beloved person is prioritized as the source of what the lover values in them. On the former, love consists in the lover's responding to qualities which are valued in, and perceived or believed to be had by, the beloved (the responsiveness account); whereas on a rival view, love is not thus responsive to a lover's characteristics or merits, but rather love consists in the lover's selecting one whom they will to love, and what is valued in the beloved by the lover arises out of this loving relation (the volitional account). ${ }^{29}$ But the responsiveness view, though it articulates the reasons why someone might love another, loses sight of the person who is loved; it would predict that we'd equally love anyone who possesses the relevant qualities, and it cannot make sense of why love is (or ought to be) constant throughout changes in someone's qualities. And the volitional view has the opposite problem of not identifying reasons for loving a particular person linked to their qualities, since the qualities valued by a lover only emerge out of the fact of being loved.

Niko Kolodny's (2003) relationship theory aims to improve on these two

\footnotetext{
${ }^{29}$ These labels are due to Stump 2006, and 2010, Chap. 5. See Taylor 1976 and (arguably) Velleman 1999 for responsiveness accounts, and Frankfurt 2004 for the volitional account.
} 
opposing views: on it, love is valuing a relationship with another, such that no non-relational feature can be what gives one a reason for loving someone: "one's reason for loving a person is one's relationship to her: the ongoing history that one shares with her" $\left(2003,135^{-136)}\right.$.

Love is ... rendered normatively appropriate by the presence of a relationship. Love, moreover, partly consists in the belief that some relationship renders it appropriate, and the emotions and motivations of love are causally sustained by this belief (except in pathological cases). (146)

On this view, however, it is irrational (even if possible) to love some individuals, namely those with whom one lacks a relational history.

By contrast, Kieran Setiya (2014, draft) argues for a permissive account of love, on which it can be rational for any of us to love any other human being, without having any common history or past relationship with them. Setiya insists that the reasons for loving someone need not be based on their particular merits or virtues but rather, that "another's humanity is sufficient reason to love them: no one is unworthy of love" (2014, 248). As Setiya recently qualifies this view, "it is rational to love any human being with whom you are personally acquainted, not any human being, full stop" (draft, 4 ). For Setiya "personal acquaintance" refers to whatever cognitive contact makes possible love at first sight, and justifies concern for individuals as such. This latter kind of concern is ethically significant in that it can make it rational to give priority to helping one person instead of (say) three; this is possible, argues Setiya, in cases where you are personally acquainted with the one, but the other three are strangers.

Now one might balk at attempting to adopt either such view of human love in order to illuminate an account of divine love, on the grounds that God vastly different from humans by being their ultimate creator and given the gulf between divine goodness and humanity's imperfection. ${ }^{30}$ Nevertheless, those religions which attribute to God the property of being loving, indeed being

$3^{30}$ Though see Rea 2018, Chap. 5, for an argument that divine love should not be identified with idealized human love. 
the moral exemplar of love, will need to appeal to some relevant connections insofar as it makes any sense at all to call God loving.

Many will find features of the permissive view a better fit for God's love of humanity: for not only does their humanity perhaps confer on them a special role in God's creative order, that role also justifies, given God's moral perfection, a sacrificial concern for their well-being. On a naïve, flat-footed application of the relationship view, by contrast, God would lack reasons for loving those persons with whom God does not yet have any personal relational history. Yet a more sophisticated application might insist that God at least retains, for all created persons, the crucial relation of being personal creator and sustainer of created persons; and for those theological traditions which claim that human persons are special by being created in God's likeness or image, those persons have a special personal relational history whether or not they later have the kind of interpersonal relations that make for interpersonal knowledge. So even if God lacks interpersonal knowledge of some persons, God could perhaps still be related enough to possess reasons for loving them. But on either the permissive or the relationship view, God is better positioned to love them by giving them God's very self through interpersonal knowing, once God knows them personally. Indeed, the state of minds which comprises interpersonal knowledge satisfies part of the Thomistic ideal on which the lover "desires union with the beloved": ${ }^{31}$ God is importantly united in a personal relation with those whom God knows personally. Those who know God personally are better positioned to recognize God's blessings or instruction as being given by God: such recognition makes possible responsive attitudes such as gratitude to God or listening for the divine voice, which in turn informs one's motivation for and commitment to a range of actions. The interpersonal knowing relation also seems to underpin the reception and function of forgiveness, which for many theistic traditions is central to divine love: if forgiveness is normatively significant in that alters the operative norms bearing on the interaction between the wronged and the wrongdoer, ${ }^{32}$ then the relational interactions constitutive of interpersonal knowing would play

${ }^{31}$ See Stump 2010, Chaps. 5-6. I do not suppose that my interpersonal knowledge supercedes her account of the medieval view of union with God (in her Chap. 6), though as I've argued above, I think it contributes more to it than her own Franciscan knowledge.

$3^{2}$ See especially Warmke 2016 and 2017, and Strabbing 2017. 
a fundamental role. Thus even on the relationship view of love, it could be constitutive of God's love that God pursues interpersonal knowledge with all human persons; and when achieved, such knowledge will play a pivotal role in the psychology and action of the one who knows God.

\section{Epistemic Injustice toward God and Neighbor}

Interpersonal knowledge thus yields payoffs for several familiar areas of philosophy of religion adumbrated above. In this final section, I shall argue that interpersonal knowledge also emerges as relevant to social epistemology in a manner as yet unappreciated, namely, given the import of epistemic injustice and the ways it may surface in religious matters.

Arguably a kind of epistemic harm arises in cases where a knower's testimony is dismissed, or their credibility downgraded, due to a specific form of prejudice (see esp. Fricker 2007, Medina 2013, Dotson 2011, 2014).33 Where social generalizations promote identity prejudice against certain individuals simply because they are part of a given social group, there can arise systematic imbalances in whose testimony is received as credible. This leads to patterns of injustice where individuals, due to their social identities (e.g. as women, or persons of color), are not treated as fully worth listening to, even regarding their own experiences; their stories are marginalized, reinterpreted, summarily dismissed, or otherwise treated as less credible. Such patterns involve a distinctly epistemic form of injustice, because when hearers regard such speakers as less credible than they are as a result of such prejudice, the speakers are harmed in their capacities as knowers.

Such prejudices are insidious partly because they may function as part of a culture's social imagination, and with affective investment, without residing in an individual's beliefs about those within the social category. ${ }^{34}$ These are most pervasive when the prejudices which give rise to them are systematic (rather than localized), and often linked to more than one social prejudicial category; they are thus capable of causing persistent (rather than inci-

\footnotetext{
${ }^{33}$ For an overview, see McKinnon 2016, as well as the more focused contributions to Kidd, Medina, and Pohlhaus 2017.

${ }^{34}$ Thus such injustice can be produced even by those who do not believe the negative social stereotypes which nevertheless shape how they consume or respond to others' testimony.
} 
dental or occasional) harms. The harm involved is ethical but importantly epistemic: a speaker suffering from what Fricker calls "identity-prejudicial credibility deficit" is harmed in their "capacity as a giver of knowledge," for their testimony is not believed, or regarded as credible enough to raise significantly the hearer's confidence in what is testified to. To be prejudicially excluded in this way from the communal exchange of knowledge impugns the speaker's epistemic trustworthiness: they are effectively treated as either incompetent or insincere (or both). But because the capacity to give knowledge to others is central to human rationality, and thereby, to an essential aspect of human value, to harm them in this capacity is to symbolically degrade someone as less than fully human (Fricker 2007, 43-47). If persistent and systematic, it can also contribute detrimentally to one's loss of confidence in what one knows (thereby robbing them of particular knowledge), and in one's general abilities as a knower, even preventing them from developing intellectual virtues such as intellectual courage, impartiality, and intellectual sobriety $(2007,49-50)$. Such injustices can even play decisive roles in hindering vulnerable and marginalized members of such social groups from becoming the kind of person they are capable of being $\left(2007,53^{-56)}\right.$ : they may live into the stereotyped patterns which express their diminished epistemic (and so$\mathrm{cial} /$ political) worth, acceding to related distorted images consistent with such generalizations.

Though most work on epistemic injustice has focused on the social categories of race or gender or class, religion is also a relevant social type. ${ }^{35}$ One could identify religious associations systematically linked with other prejudicial identity stereotypes, which could in turn suggest how religion qua social type can contribute (either positively and negatively) to a hearer's prejudicial judgment of a speaker's credibility. The central case of interest would be negative religious identity prejudice which would contribute to testimonial injustice toward speakers testifying on certain matters of religion. No doubt there could be many different sorts of cases. But I shall focus our attention on two kinds of harm: harm toward other human persons, even among those who share a broad religious identity; and toward God as one who speaks to us.

${ }^{35}$ As noted by Fricker $(2007,27,53-4)$. Kidd 2017 discusses epistemic injustice and religion, but does not consider the issues raised here. 
For each kind, part of the epistemic harm involves the injustice of imposing a diminished capacity for gaining interpersonal knowledge.

Among fellow humans, there is the case where a religious speaker might suffer credibility deficit from those who regard their testimony concerning matters linked to their religious views (whether doctrinal, moral, spiritual, etc.) to be less than credible owing to an identity prejudice centered on their specific religious identity. Such prejudice may be construed narrowly, being either inter-religious in virtue of disagreement between those of different religious traditions (e.g., the disagreements between Christians and Muslims); or a prejudice may even be intra-religious, such that the zealously dogmatic within a religious tradition is dismissive toward fellow adherents whom they regard as offering mistaken views of doctrine, morality, spiritual direction, and so on. ${ }^{36}$ Alternatively the identity prejudice might be construed more broadly, what we might call extra-religious. This might occur when an atheist or agnostic, who is willing to disavow (nearly) any religious belief as being tainted with falsity or other epistemically dubious properties, deems the religious speaker as not due a hearing; on the other hand, it might also involve religious hearers being unwilling to take seriously a non-theist's testified objections or reservations about religion, or their testimony of their experiences living without religious commitments. The important feature is that the speaker's religious identity in one way or another provides the prejudicial hearer with their grounds for downgrading the speaker's credibility. Of course, such prejudice only harms the testifier in their capacity as a knower where the religious speaker is correct and even knows what they testify to; but we are presupposing here that there is a God and that at least sometimes, a religious individual could be correct and also know some of what they claim. Downgrading a speaker's credibility due to religious identity prejudice harms speakers who could share propositional knowledge concerning religion by testimony; and even where such speakers lack propositional knowledge, rejection of their testimony will also inhibit others from learning the more qualitative knowledge concerning what-it-is-like to practice and live

\footnotetext{
${ }^{36}$ E.g. within Christianity, between Eastern and Western traditions (e.g. on the filioque controversy), or between Catholics and Protestants (on a wide range of doctrines), or among Protestants, between (e.g.) Reformed and Methodist theologies (or ecclesiologies, etc.).
} 
from within a religious (or non-religious) perspective.

Yet whether inter-, intra-, or extra-religious in nature, cases of epistemic injustice, or even perceived injustice, can plausibly hinder people from entering into the kinds of interpersonal relations which enable one to know one another interpersonally. Because people naturally befriend and associate more with those who think like them, particularly in their social identities, these are the people whom they most often come to know personally. Though people often meet others due to sheer circumstance, even these encounters are typically guided by the structures of who knows whom; and we are more often led into circles of acquaintance by the very relations of interpersonal knowledge which are upheld for how they bind us to those with shared social identity, including religion. The intersectionality of religion with other social categories such as race or ethnicity, gender, sex, sexual orientation, or economic opportunity is relevant insofar as they contribute to how and whether people become parts of communities which cluster around such shared affiliations. ${ }^{37}$

The present point is that when testimonial injustice owing in part to religious difference closes off opportunities to know others personally (or to come to know them better), this can create further systematic relational injustices across not only religious lines but also those of race, gender, sexuality, and so on. When such relational avenues are closed off, inter-religious dialogue is hindered, and intra-religious discord is exacerbated. And when this happens, extra-religious discourse between the religious and non-religious is weakened, leading to suspicion, subtle or overt insults, and accusations of closed-mindedness. Indeed, the very idiom of being "closed-minded" gains new meaning given our gloss on interpersonal knowledge: the "state of minds" which constitutes knowing another personally is unavailable to those unwilling to enter into interpersonal relationship across religious differences. ${ }^{38}$

The fragmenting of communities across intersectional identities related to religion as a result of systematic testimonial injustice is its own sort of injustice. Social discord is sewn when religious diversity and its disagree-

\footnotetext{
${ }^{37}$ For important theological work on these issues with respect to race, see especially Jennings 2010 and Bantum 2016; for a sociological study of race and American Christianity, see Emerson and Smith 2000.

${ }^{38}$ Medina makes similar points concerning the need for what he calls "epistemic interaction" $(2013,7-12)$.
} 
ments foster belief polarization rather than genuine dialogue borne of humility. Where interpersonal knowledge relations are reduced or made more difficult, opportunities for and interest in cross-religious dialogue naturally diminish and eventually become widely regarded as undesirable (often, in some contexts, with oppressive and violent consequences). Since we should care about the flourishing of all in religiously diverse and (aspirationally) pluralistic societies, we should instead strive to learn from and relate to those religiously different from ourselves. While such efforts can represent the first steps toward mutual understanding, these steps are unlikely to be taken unless people of good will, regardless of religious identity, work toward knowing one another on relational terms in spite of, and even for the sake of, their religious differences. Yet when such differences are valued and embraced, this in turn promotes relations of trust across such differences, ${ }^{39}$ and makes us more available for, and even interested in, knowing and understanding others well.

What of God as knowing subject? Assuming a God who somehow speaks to us, $4^{0}$ in what sense could it be possible, through ignoring or rejecting divine testimony, to harm God in God's capacity as a knower? After all, God is omniscient by knowing all truths that can be known, and thus God would know everything about us (similarly, God would have all qualitative knowlege about us). And God presumably cannot be made less omniscient in these senses by our failing to hear or believe or respond to God's testimony to us. Any harm there might be would not, it seems clear, affect God's propositional omniscience, what propositions God knows; rather, it could affect which persons God (personally) knows.

Recall that there will be many individuals who fail to relate to God secondpersonally: this will include the many who dismiss (or are otherwise unduly skeptical of) the very possibility of God speaking to them because they insist that God does not exist. Similarly for those who may believe (intellectually) that there is a deity but who fail (or refuse) to engage in religious devotional practices of prayer or worship: insofar as these practices involving secondpersonal treatment of God are essential for one to become interpersonally

${ }^{39}$ Cf. Pohlhaus, Jr. 2017 and Hawley 2017.

$4^{\circ}$ On which see Wolterstorff 1995 , and Cuneo 2016, Chap. 6. 
acquainted with God, not participating in them results in not having treated God as a subject. These individuals will not gain testimonial knowledge of what God is communicating, but on our account of interpersonal knowledge they also, given Symmetry, can prevent God from acquiring interpersonal knowledge of themselves. In this way, they would harm God in God's own capacity to know them interpersonally; or at the very least, we may say that they thereby prevent God from knowing them interpersonally, for by being free to reject God's existence or communications, they have a role to play in permitting themselves to be known by God. As we gestured at earlier (in section 3.3), God's pursuit of knowing us interpersonally is arguably constitutive of divine love for us, and such interpersonal knowledge is bound up with the relational functions of divine forgiveness and its spiritual reception in terms of repentance for $\sin$. If so, then our freedom ${ }^{4}$ whether to relate to God in the manner required means we are in a position to frustrate not only God's efforts to love us on relational terms, but also to impede the divine epistemic enterprise of coming to know us personally.

Some theists, however, may want to reconceive the relation of knowing personally in the divine case, such that God know us personally even if we do not know God. This alternative view would reject SYMMETRY at least for how God knows us. Such a position might grant that SYMMETRY is necessary for human interpersonal knowledge, but that God's ability to know us personally is far different in that God's personal knowledge of us can be one-directional, not requiring our cooperation. A theist might be driven to such a view by considerations stemming from doctrines concerning divine impassibility or divine aseity; or perhaps such a theist regards divine knowledge of any kind to be unaffected by anything which a human person might do or fail to do. In particular, one might conceive of the sort of epistemic injustice or oppression sketched earlier to be possible only where the harmed knower stands in a subjugated position given the power relations between the would-be hearer

\footnotetext{
${ }^{41}$ Significant questions arise for strong sovereignty theologies, such as Reformed views descending from Calvin or Edwards, on which people are not significantly free (e.g., in the incompatibilist sense) in any of their decisions. For if some are not free to refrain from treating God second-personally, and others are not free to do so, it is more difficult to conceive of the two-way second personal interactions described in ENCOUNTER as being reciprocal in the relevant sense. However, I do not have space to consider these issues at length here.
} 
and the testifying knower. But in the divine case, a theist might on theological grounds reject that a human could ever stand in the requisite position of (epistemic) power over God. $4^{2}$

Whatever the rationale, note that even on a rival view of knowing personally that abandons SYMMETRY at least for divine knowledge of us, ENCOUNTER itself offers grounds for denying that God knows personally many who fail to respond in second-personal terms to God's testimonial communication to us. For in not responding, the contact between such persons and God is not reciprocal, thus failing ENCOUNTER's clause (i) on which the causal contact must be reciprocal; and it would also fail ENCOUNTER's clause (iii), which requires the known person to treat the knower second-personally.

Thus such a revision of what interpersonal knowledge amounts to in the divine case toward us will stand in need of elaborate recasting in order to articulate alternative principles which provide an account of how God knows us; for neither SyMmetry nor ENCOUNTER as stated will suit the needs of such an alternative account. Even if developing such an account may be accomplished to this theist's satisfaction, it will remain the case that the sort of interpersonal knowledge commonly had between humans is something which God does not have with many human persons. Yet if an alternative theistic account of divine knowledge of persons nevertheless makes room for the idea that between humans our interpersonal knowing amounts to a genuine epistemic relation, such an account will have to concede that it is an epistemic relation which God can lack, and has lacked, toward some individuals.

\section{Conclusion}

Interpersonal knowledge has not been given nearly the attention that other ideas in epistemology have received, and this even as social epistemology has recently blossomed. Yet the time seems ripe to explore it in its own right, and

\footnotetext{
${ }^{4}$ Some might balk at using the label of epistemic injustice here, on the grounds that we cannot be unjust toward God (perhaps, at most, we can be impious toward God); if so, perhaps this should be called "epistemic impiety." Whatever labels one prefers, the idea sketched above is, I hope, clear enough to grasp. (Thanks to Christina Van Dyke here.)
} 
to assess how relevant it can be to a range of issues in epistemology, the epistemology of religion, philosophy of religion, and analytic theology. Arguably, interpersonal knowledge can also enhance several Christian theological doctrines which we have not been able to consider: for example, the doctrine of ineffability (see Keller forthcoming), the indwelling of the Holy Spirit (see Alston 1989), the Eastern Orthodox conception of theosis (see Jacobs 2009), or the social conception of the Trinity. ${ }^{43}$

I have argued here for developing the contours of some recent approaches to knowing others interpersonally, and have suggested the significant impacts it can have on skepticism from divine hiddenness, the epistemology of liturgy, understanding divine love, and for newer issues of epistemic injustice toward God and neighbor. Though these treatments have needed to be somewhat cursory, they lay the foundation for re-envisioning issues at the intersection of epistemology and religion. ${ }^{44}$

Seattle Pacific University

${ }^{43}$ A quick sketch: one can say that the joint state of mind had between the Father and Son, or the Spirit and Father, or the Son and Spirit, constitute the shared (mental) state understood mereologically, in terms of mutual parthood, which offers a coherent model of their mutual indwelling (see Cotnoir 2017 for such a mutual parthood account). On such an approach, the divine persons indwell one another by sharing a joint mental state of interpersonal knowledge, where this state is a part mutually had in virtue of their mereological relations to one another. In Cotnoir's terminology, "every person [of the Trinity] is a mutual part of every other person of the Trinity" $(2017,134)$. I develop some of these ideas in other work.

${ }^{44}$ For helpful discussion and comments on earlier versions of some of these ideas, many thanks to Robert Adams, Charity Anderson, Max Baker-Hytch, Laura Benton, Billy Dunaway, David Efird, Jonathan Kvanvig, John Hawthorne, Steve Layman, Patrick McDonald, Michael Pace, Dani Rabinowitz, Rebekah Rice, Leland Saunders, Christina Van Dyke, and to two helpful anonymous referees. I am grateful also to audiences or reading groups at Baylor University, York University, the University of Oxford, the University of Notre Dame, Seattle Pacific University, and the SCP group session at the Pacific APA (2018). This paper was also made possible through a faculty research and scholarship grant (Seattle Pacific University, summer 2017), and through the support of grants from the John Templeton Foundation (at Oxford and then at Notre Dame). The opinions expressed in this publication are those of the author and do not necessarily reflect the views of the John Templeton Foundation. 


\section{References}

Adams, Marilyn McCord. 1995. "Praying the Proslogion: Anselm's Theological Method." In Thomas D. Senor (ed.), The Rationality of Faith and the Plurality of Belief, 13-39. Ithaca: Cornell University Press.

Alston, William P. 1989. "The Indwelling of the Holy Spirit." In Divine Nature and Human Language, 223-252. Ithaca: Cornell University Press.

Bantum, Brian. 2016. The Death of Race: Building a New Christianity in a Racial World. Minneapolis: Fortress Press.

Barth, Karl. 1975. Church Dogmatics, volume I.1. Edinburgh: T \& T Clark, 2nd edition.

—. 2000 [1957]. Church Dogmatics, volume II.1. Edinburgh: T \& T Clark.

Beeley, Christopher A. 2008. Gregory of Nazianzus on the Trinity and the Knowledge of God. Oxford Studies in Historical Theology. Oxford: Oxford University Press.

Benton, Matthew A. 2017. "Epistemology Personalized." Philosophical Quarterly 67: 813-834.

Broad, C.D. 2014 [1925]. The Mind and its Place in Nature. London: Routledge.

Brunner, Emil. 1943. The Divine-Human Encounter. Philadelphia: Westminster Press.

Buber, Martin. 1970 [1923]. I and Thou. New York: Touchstone.

Coakley, Sarah. 2013. "Beyond 'Belief': Liturgy and the Cognitive Apprehension of God.” In Tom Greggs, Rachel Muers, and Simeon Zahl (eds.), The Vocation of Theology Today, 130-145. Eugene: Wipf \& Stock.

Cockayne, Joshua. 2017. "Contemporaneity and Communion: Kierkegaard on the Personal Presence of Christ." British Journal for the History of Philosophy 25: 41-62.

Code, Lorraine. 2015. "Taking Subjectivity into Account." In Ann Garry and Marilyn Pearsall (eds.), Women, Knowledge, and Reality: Explorations in Feminist Philosophy, 191-221. New York: Routledge, 2nd edition.

Cotnoir, A.J. 2017. "Mutual Indwelling." Faith and Philosophy 34: 123-151. 
Cullison, Andrew. 2010. "Two Solutions to the Problem of Divine Hiddenness." American Philosophical Quarterly 47: 119-134.

Cuneo, Terence. 2016. Ritualized Faith: Essays on the Philosophy of Liturgy. Oxford: Oxford University Press.

Dotson, Kristie. 2011. “Tracking Epistemic Violence, Tracking Practices of Silencing." Hypatia 26: 236-257.

—. 2014. "Conceptualizing Epistemic Oppression." Social Epistemology 28: $115^{-138 .}$

Dunaway, Billy and Hawthorne, John. 2017. "Scepticism." In William J. Abraham and Frederick D. Aquino (eds.), The Oxford Handbook of the Epistemology of Theology, 290-308. Oxford: Oxford University Press.

Eilan, Naomi. 2014. “The You Turn.” Philosophical Explorations 17: 265-278.

Eilan, Naomi (ed.). 2016. The Second Person: Philosophical and Psychological Perspectives. Abingdon: Routledge.

Emerson, Michael O. and Smith, Christian (eds.). 2000. Divided by Faith: Evangelical Religion and the Problem of Race in America. Oxford: Oxford University Press.

Feldbacher, Christian J. 2012. "Knowledge by Narratives: On the Methodology of Stump's Defence.” European Journal for Philosophy of Religion 4: 155-165.

Fischer, John Martin. 2012. "Struggling with Evil: Comments on Wandering in Darkness." European Journal for Philosophy of Religion 4: 109-122.

Flew, Antony and MacIntyre, Alasdair (eds.). 1955. New Essays in Philosophical Theology. London: SCM Press.

Frankfurt, Harry G. 2004. The Reasons of Love. Princeton: Princeton University Press.

Fricker, Miranda. 2007. Epistemic Injustice: Power and the Ethics of Knowing. Oxford: Oxford University Press. 
Goldman, Alvin I. 2006. Simulating Minds: The Philosophy, Psychology, and Neuroscience of Mindreading. New York: Oxford University Press.

- 2013. Joint Ventures: Mindreading, Mirroring, and Embodied Cognition. New York: Oxford University Press.

Goodman, Jeremy and Lederman, Harvey. unpub. "Verbalism.” 2018 draft.

Greco, John. 2008. "Friendly Theism.” In James Kraft and David Basinger (eds.), Religious Tolerance through Humility, 51-58. Abingdon: Routledge.

—. 2015. "No-Fault Atheism." In Adam Green and Eleonore Stump (eds.), Hidden Divinity and Religious Belief: New Perspectives, 109-125. Cambridge: Cambridge University Press.

- 2017. "Knowledge of God." In William J. Abraham and Frederick D. Aquino (eds.), The Oxford Handbook of the Epistemology of Theology, 9-29. Oxford: Oxford University Press.

Hawley, Katherine. 2017. "Trust, Distrust, and Epistemic Injustice." 69-78. In Kidd et al. (2017).

Hawthorne, John. 2004. Knowledge and Lotteries. Oxford: Clarendon Press.

Jackson, Frank. 1982. "Epiphenomenal Qualia." Philosophical Quarterly 32: 127-136.

—. 1986. "What Mary Didn't Know.” Journal of Philosophy 83: 291-295.

Jacobs, Jonathan D. 2009. "An Eastern Orthodox Conception of Theosis and Human Nature." Faith and Philosophy 26: 615-627.

James, William. 1912. The Will to Believe, and Other Essays in Popular Philosophy. New York: Longmans, Green, and Co.

Jennings, Willie James. 2010. The Christian Imagination: Theology and the Origins of Race. New Haven: Yale University Press.

Keller, Lorraine Juliano. forthcoming. "Divine Ineffability and Franciscan Knowledge.” Res Philosophica . 
Kidd, Ian James. 2017. “Epistemic Injustice and Religion.” In Ian James Kidd, José Medina, and Gaile Pohlhaus (eds.), The Routledge Handbook of Epistemic Injustice, 386-396. New York: Routledge.

Kidd, Ian James, Medina, José, and Pohlhaus, Gaile (eds.). 2017. The Routledge Handbook of Epistemic Injustice. New York: Routledge.

Kierkegaard, Søren. 1990 [1843-44]. Eighteen Upbuilding Discourses. Princeton: Princeton University Press.

— $199^{2}$ [1846]. Concluding Scientific Postscript to Philosophical Fragments, volume 1. Princeton: Princeton University Press.

Kolodny, Niko. 2003. "Love is Valuing a Relationship." Philosophical Review 112: 135-189.

Kripke, Saul. 1972. Naming and Necessity. Harvard University Press.

Lauer, David. 2014. "What Is It to Know Someone?" Philosophical Topics 42: 321-344.

Lewis, C.S. 1955. “On Obstinacy in Belief.” The Sewanee Review 63: 525-538.

McGrath, Matthew. 2017. "Knowing What Things Look Like." Philosophical Review 126: 1-41.

McGuigan, Colin M. and Kallenberg, Brad J. 2017. "Ecclesial Practices.” In William J. Abraham and Frederick D. Aquino (eds.), The Oxford Handbook of the Epistemology of Theology, 141-156. Oxford: Oxford University Press.

McKinnon, Rachel. 2016. "Epistemic Injustice.” Philosophy Compass 11: 437-446.

Medina, José. 2013. The Epistemology of Resistance: Gender and Racial Oppression, Epistemic Injustice, and Resistant Imaginations. Oxford: Oxford University Press.

Mitchell, Basil (ed.). 1958. Faith and Logic: Oxford Essays in Philosophical Theology. London: George Allen \& Unwin.

Mitchell, Basil. 1973. The Justification of Religious Belief. New York: Seabury Press.

Moser, Paul K. 2008. The Elusive God: Reorienting Religious Epistemology. Cambridge: Cambridge University Press. 
- 2010. The Evidence for God: Religious Knowledge Reexamined. Cambridge:

Cambridge University Press.

—. 2014. "The Virtue of Friendship with God." In Laura Frances Callahan and Timothy O'Connor (eds.), Religious Faith and Intellectual Virtue. Oxford: Oxford University Press.

Nagel, Jennifer. 2013. "Knowledge as a Mental State.” Oxford Studies in Epistemology 4: $273-308$.

Pohlhaus, Gaile. 2017. "Varieties of Epistemic Injustice." 13-26. In Kidd et al. (2017).

Rawls, John. 2009. A Brief Inquiry into the Meaning of Sin and Faith: with "On My Religion”. Cambridge: Harvard University Press.

Rea, Michael C. 2009. "Narrative, Liturgy, and the Hiddenness of God." In Kevin Timpe (ed.), Metaphysics and God: Essays in Honor of Eleonore Stump, 76-96. New York: Routledge.

- 2018. The Hiddenness of God. Oxford: Oxford University Press.

Schellenberg, J. L. 2008. "What Divine Hiddenness Reveals.” https://infidels.org/library/modern/john_schellenberg/hidden.html.

Schellenberg, J.L. 1993. Divine Hiddenness and Human Reason. Ithaca: Cornell University Press.

- 2015a. "Divine Hiddenness and Human Philosophy." In Adam Green and Eleonore Stump (eds.), Hidden Divinity and Religious Belief: New Perspectives, 13-32. Cambridge: Cambridge University Press.

—. 2015b. The Hiddenness Argument. Oxford: Oxford University Press.

Schieber, Joseph. 2017. "Looks and the Immediacy of Visual Objectual Knowledge.” Analysis doi:doi.org/10.1093/analys/anx126.

Setiya, Kieran. 2014. "Love and the Value of a Life." Philosophical Review 123: 251-280.

—. draft. "Other People." Https://philpapers.org/rec/SETOP. 
Sliwa, Paulina. 2018. "Know-How and Acts of Faith." In Matthew A. Benton, John Hawthorne, and Dani Rabinowitz (eds.), Knowledge, Belief, and God, 246-263. Oxford: Oxford University Press.

Smedt, Johan De and Cruz, Helen De. 2015. "The Epistemic Value of Speculative Fiction." Midwest Studies in Philosophy 34: 58-77.

Strabbing, Jada Twedt. 2017. "Divine Forgiveness and Reconciliation.” Faith and Philosophy 34: 272-297.

Stump, Eleonore. 2006. "Love, By All Accounts." In Proceedings and Addresses of the American Philosophical Association, volume 8o, 25-43.

- 2009. "The Problem of Evil: Analytic Philosophy and Narrative." In Oliver D. Crisp and Michael C. Rea (eds.), Analytic Theology, 251-265. Oxford: Oxford University Press.

- 2010. Wandering in Darkness: Narrative and the Problem of Suffering. Oxford: Clarendon Press.

—. 2012. "Wandering in Darkness: Further Reflections." European Journal for Philosophy of Religion 4: 197-219.

- 2013. "Omnipresence, Indwelling, and the Second-Personal." European Journal for Philosophy of Religion 5: 29-53.

—. 2017. "Theology and the Knowledge of Persons." In Fiona Ellis (ed.), New Models of Religious Understanding, 172-19o. Oxford: Oxford University Press.

Talbert, Bonnie M. 2015. "Knowing Other People: A Second-Person Framework.” Ratio 28: 190-206.

Taylor, Gabriele. 1976. "Love." Proceedings of the Aristotelian Society . van Fraassen, Bas C. 2002. The Empirical Stance. New Haven: Yale University Press. Velleman, J. David. 1999. "Love as a Moral Emotion.” Ethics 109: 338-374.

Warmke, Brandon. 2016. "The Normative Significance of Forgiveness." Australasian Journal of Philosophy 94: 687-703.

—. 2017. "God's Standing to Forgive." Faith and Philosophy 34: 381-402. 
Wielenberg, Erik J. 2008. God and the Reach of Reason: C.S. Lewis, David Hume, and Bertrand Russell. Cambridge: Cambridge University Press.

Williamson, Timothy. 2000. Knowledge and its Limits. Oxford: Oxford University Press.

- 2009. "Replies to Critics." In Patrick Greenough and Duncan Pritchard (eds.), Williamson on Knowledge, 279-384. Oxford: Oxford University Press.

Wolterstorff, Nicholas. 1995. Divine Discourse: Philosophical Reflections on the Claim that God Speaks. Cambridge: Cambridge University Press.

—. 2016. "Knowing God Liturgically.” Journal of Analytic Theology 4: 1-16.

- 2018. Acting Liturgically: Philosophical Reflections on Religious Practice. Oxford: Oxford University Press. 